\title{
PERAN DINAS KESEHATAN DALAM MENANGGULANGI GIZI BURUK ANAK DI KECAMATAN NGAMPRAH KABUPATEN BANDUNG BARAT
}

\author{
Indra Slamet Gumelar1) \\ 1)Jurusan Ilmu Pemerintahan, Fakultas Ilmu Sosial dan Ilmu Politik Universitas \\ Jenderal Achmad Yani
}

\begin{abstract}
Abstrak
Judul penelitian ini adalah "Peran Dinas Kesehatan Dalam Menanggulangi Gizi Buruk Anak Di Kecamatan Ngamprah Kabupaten Bandung Barat”. Masalah dalam penelitian ini belum optimalnya pelaksanaan Dinas Kesehatan Dalam Menanggulangi Gizi Buruk Anak Di Kecamatan Ngamprah Kabupaten Bandung Barat. Metode penelitian yang peneliti gunakan adalah metode penelitian bersifat deskriptif dengan pendekatan kualitatif. Teknik penentuan informan yang digunakan adalah teknik purposive sampling. Hasil penelitian menunjukkan bahwa dalam melaksanakan tugas dan fungsinya dinas kesehatan Dinas Kesehatan sudah melaksanakan peran cukup optimal dilihat dari enam indikator keberhasilan penanggulangan gizi buruk yaitu : Seluruh Posyandu melaksanakan operasi timbang minimal sekali sebulan Seluruh balita ditimbang, Seluruh kasus gizi buruk dirujuk ke Puskemas Perawatan atau Rumah Sakit, Seluruh kasus gizi buruk dirawat di Puskesmas Perawatan atau runah sakitditangani sesuai tatalaksana baita gizi buruk. Seluruh balita gizi buruk pasca perawatan mendapatkan pendampingan.
\end{abstract}

Kata kunci: Peran, Gizi Buruk

\begin{abstract}
The title of this research is "The Role of the Health Office in Tackling Child Malnutrition in Ngamprah District, West Bandung Regency". The problem in this research is not yet optimal implementation of the Health Office in Overcoming Malnutrition in Children in Ngamprah District, West Bandung Regency. The research method that researchers use is descriptive research methods with a qualitative approach. The technique of determining the informants used was purposive sampling technique. The results showed that in carrying out its duties and functions, the health office, the Health Office had implemented a sufficiently optimal role seen from the six indicators of success in overcoming malnutrition, namely: All Posyandu carry out weighing operations at least once a month All toddlers are weighed, All cases of malnutrition are referred to the Puskemas Nursing or Home Sick, all cases of malnutrition are treated at the health center. Nursing or hospitalization is handled according to the management of malnutrition. All post-treatment malnourished toddlers receive assistance.
\end{abstract}

Key words: Role, Malnutrition

\section{PENDAHULUAN}

Keberhasilan pembangunan nasional yang diupayakan oleh pemerintah sangat ditentukan oleh ketersediaan sumber daya manusia. 
Mutu sumber daya manusia merupakan salah satu faktor kemajuan suatu bangsa. Dalam rangka meningkatkan mutu SDM, tidak terpisah dari peningkaan faktor pendidikan, kesehatan dan ekonomi dimana ketiga faktor tersebut erat kaitannya dengan keberhasilan gizi manusia. Sebagai salah satu faktor vital untuk meningkatkan mutu SDM, faktor kesehatan mempengaruhi aktivitas manusia untuk bekerja dan manusia memerlukan gizi yang cukup sebagai sumber energi untuk melaksanakan berbagai aktivitas.

Dalam mewujudkan pembangunan nasional khusunya pada sektor kesehatan, pembangunan diarahkan untuk meningkatkan derajat kesehatan masyarakat guna terciptanya tujuan bersama yaitu kesejahteraan dan pembangunan nasional jangka panjang. Hal ini dijelaskan dalam Undang-Undang

Nomor 17 tahun 2007 tentang Rencana Pembangunan Jangka Panjang Nasional (RPJPN) menetapkan bahwa :

"Salah satu tujuan pembangunan nasional yang ingin dicapai adalah mewujudakan daya saing bangsa. Status Kesehatan dan Gizi merupakan salah satu komponen penting dalam peningkatan kualitas sumber daya manusia dalam rangka meningkatkan daya saing bangsa yang pelaksanaannya dilakukan secara bertahap sesuai dengan Rencana Pembangunan Jangka Menengah Nasional.”

Pelayanan di bidang kesehatan merupakan salah satu bentuk pelayanan kesehatan yang paling dibutuhkan oleh masyarakat. Pelayanan kesehatan yang dimaksud tentunya ialah pelayanan yang cepat, tepat, murah serta ramah. Berangkat dari kesadaran tersebut puskesmaspuskesmas yang ada di daerah wajib memberikan bentuk pelayanan yang prima kepada setiap pasien.

Penanganan gizi buruk sangat terkait dengan strategi sebuah bangsa dalam menciptakan sumber daya manusia yang sehat, cerdas, dan produktif. Upaya peningkatan sumber daya dimulai dengan cara penanganan pertumbuhan anak sebagai bagian keluarga dengan asupan gizi serta perawatan yang baik, dengan lingkungan keluarga yang sehat hadirnya penyakit infeksi atau menular lainnya dapat dihindari dan 
pelayanan kesehatan primer sangat menentukan dalam membentuk anak yang terhindar dari gizi buruk. Secara makro, dibutuhkan ketegasan strategi, regulasi serta koordinasi dari pemerintah dengan dinas kesehatan serta kesadaran masyarakat terhadapan bahayanya yang timbul dari kasus gizi buruk yang menimpa anak.

United Nations Development Programme (UNDP) report tahun 2014, melaporkan bahwapada tahun 2014, Indeks Pembangunan Manusia (IPM) Indonesia menduduki peringkat 110 dari 187 negara di dunia. Sedangkan pada tahun sebelumnya IPM Negara Indonesia menduduki peringkat 108 dari 187 negara. Data ini menunjukan bahwa IPM Indonesia mengalami penurunan dari tahun sebelumnya dan tertinggal jauh dari negeri tetangga Malaysia yang bertengger di peringkat 64 pada tahun 2013. IPM sangat dipengaruhi oleh status gizi dan kesehatan penduduk, penanganan angka kecukupan gizi buruk di Kabupaten Bandung Barat yang di dasarkan pada hasil pendataan dari Dinas Kesehatan Kabupaten Bandung Barat memicu munculnya permasalahan baru bagi pemerintahan Kabupaten Bandung Barat. Hasil pendataan menyatakan masih terdapat beberapa kecamatan di daerah Kabupaten Bandung Barat yang menderita Gizi Buruk

Berikut ini daftar kecamatan yang warganya menderita gizi buruk di Kabupaten Bandung Barat pada tahun 2016 :

Tabel 1.1

Jumlah Penderita Gizi Buruk Tahun 2016 Kabupaten Bandung Barat

\begin{tabular}{|c|c|c|}
\hline NO & $\begin{array}{c}\text { Penderita Gizi Buruk di Kabupaten } \\
\text { Bandung Barat Tahun 2016 }\end{array}$ & Jumlah Penderita \\
\hline 1 & Kecamatan Rongga & 1 orang \\
\hline 2 & Kecamatan Gununghalu & 3 orang \\
\hline 3 & Kecamatan Sindangkerta & 6 orang \\
\hline 4 & Kecamatan Cililin & 1 orang \\
\hline 5 & Kecamatan Ngamprah & orang \\
\hline 6 & Kecamatan Lembang & 6 orang \\
\hline 7 & Kecamatan Cisarua & 2 orang \\
\hline 8 & Kecamatan Cipatat & 27 orang \\
\hline & Total Penderita Gizi Buruk & \\
\hline
\end{tabular}

Pada Tabel diatas menunjukan bahwa wilayah rawan Gizi Buruk ialah Kecamatan Cililin, Sindangkerta, Gununghalu, Rongga, Cipatat, 
Cisarua hingga wilayah perkotaan seperti Kecamatan Ngamprah dan Lembang yang rawan terkena Gizi Buruk. Berdasarkan data Dinas Kesehatan (Dinkes) Kabupaten Bandung Barat pada tahun 2016 tercatat dari jumlah 137.961 anak, terdapat sebanyak 925 balita yang dikategorikan kurus karena asupan gizi, sementara itu sebanyak 24 anak atau 0,017 persen diantaranya dikategorikan sangat kurus atau gizi buruk.

Dinas kesehatan dalam hal ini berperan besar terhadap masalah gizi buruk yang diderita anak, biasanya dinas kesehatan melakukan program dengan pemberian makanan tambahan (PMT) pada gizi buruk, dalam pemberian makanan tambahan ini agar tepat sasaran, dinas kesehatan melibatkan peran serta kader posyandu di masing-masing tiap desa yang ada di kecamatan Ngamprah, kader posyandu ini telah dibekali pengetahuan serta keterampilan agar program PMT dapat tepat sasaran.

Pemerintah melalui dinas kesehatan melakukan tiga peran untuk menanggulangi gizi buruk yaitu : regulator, dinamisator dan fasilitator. Regulator disini berarti dinas kesehatan membuat regulasi atau aturan terkait program menangggulangi gizi buruk. Dinamisator dinas kesehatan berperan memberikan bimbingan pemberdayaan serta menggerakan partisipasi masyarakat untuk turut serta dalam penanggulangan masalah gizi buruk. Serta fasilitator dinas kesehatan berperan menfasilitasi masyarakat dalam menanggulangi gizi buruk meberikan pendidikan, pengetahuan serta pelatihan kepada kader-kader yang ada di posyandu agar mengetahui dasar penanggulangan terhadap masalah gizi buruk.

\section{TINJAUAN PUSTAKA}

\section{Pengertian Peran}

Biddle dan Thomas mendefinisikan peran adalah serangkaian rumusan yang membatasi perilaku-perilaku yang diharapkan dari pemegang kedudukan tertentu, merujuk pada teori peran (role theory) Biddle dan Thomas (1996:125) membagi peristilahan dalam teori peran ke dalam golongan, yaitu :

1. Orang yang mengambil bagian dalam interaksi sosial

2. Perilaku yang muncul dalam interaksi tersebut 
3. Kedudukan orang-orang dalam perilaku

4. Kaitan antara orang dan perilaku

Pendapat lain Rasyid ( 2000 : 59) Peran Pemerintah yang dimaksud antara lain :

1. Pemerintah sebagai regulator, Peran Pemerintah sebagai regulator adalah menyiapkan arah untuk menyeimbangkan penyelenggaraan pembangunan melalui penerbitan peraturan-peraturan. Sebagai regulator, Pemerintah memberikan acuan dasar kepada masyarakat sebagai instrument untuk mengatur segala kegiatan pelaksanaan pemberdayaan.

2. Pemerintah sebagai dinamisator, peran Pemerintah sebagai dinamisator adalah menggerakan partisipasi masayarakat jika tejadi kendala-kendala dalam proses pembangunan untuk mendorong dan memelihara dinamika pembangunan daerah. Pemerintah berperan melalui pemberian bimbingan dan pengarahan secara intensif dan efektif kepada masyarakat. Biasanya pemberian bimbingan diwujudkan melalui tim penyuluh maupun badan tertentu untuk memberikan pelatihan.

3. Pemerintah sebagai fasilitator, Peran Pemerintah sebagai fasilitator adalah menciptakankondisi yang kondusif bagi pelaksanaan pembangunan untuk menjembatani berbagai kepentingan masyarakat dalam mengoptimalkan pembangunan daerah. Sebagai fasilitator, Pemerintah bergerak dibidang pendampingan melalui pelatihan, pendidikan, dan peningkatan keterampilan, serta di bidang pendanaan atau permodalaan melalui pemberian bantuan modal kepada masyarakat uang diberdayakan.

\section{Tinjauan Tentang Gizi Buruk}

Menurut Departemen Kesehatan menjelaskan tentang pengertian Gizi Buruk sebagai berikut:

"Gizi Buruk atau dikenal dengan kurang energy protein merupakan keadaan kurang gizi yang disebabkan oleh rendahnya konsumsi energy dan protein dalam makanan sehari-hari sehingga tidak memenuhi angka kecukupan Gizi. Apabila Gizi Buruk disertai dengan tanda-tanda klinis seperti: wajah sangat kurus, muka seperti orang tua, perut cekung, kulit keriput disebut marasmus, dan apabila ada bengkak terutama pada kaki, 
wajah membulat dan sembab disebut kwashiorkor. Marasmus dan Kwashiorkor dikenal masyarakat sebagai "Busung Lapar"

Selanjutnya Departemen Kesehatan RI menjelaskan tentang Gizi Buruk sebagai berikut :

"Gizi Buruk bisa diartikan sebagai seseorang yang kurang gizi disebabkan oleh rendahnya konsumsi energy dan protein dalam makanan sehari-hari dan atau gangguan penyakit tertentu. Gizi buruk terjadi bila zat gizi yang diperlukan tubuh kurang sehingga menghambat pertumbuhan fisik, perkembangan otak, kemampuan efisien, kemampuan kerja dan spectrum keadaan gizi yang luas, mulai dari sekadar kegagalan pertumbuhan yang ringan sampai suatu sindrom klinis berat yang spesifik"

Tujuan mengurangi gizi buruk juga agar anak mendapatkan kesejahteraan yang telah tertuang dalam Undang-Undang Nomor 4 tahun 1979 tentang kesejahteraan anak, disebutkan bahwa:

1. Anak berhak atas kesejahteraan, perawatan, asuhan, dan bimbingan berdasarkan kasih sayang, baik dalam keluarganya maupun dalam asuhan khusus untuk tumbuh dan berkembang dengan wajar.

2. Anak berhak atas pelayanan untuk mengembangkan kemampuan dan kehidupan sosialnya, sesuai dengan kebudayaan dan kepribadian bangsa, untuk menjadi warga negara yang baik dan berguna.

3. Anak berhak atas pemeliharaan dan perlindungan, baik semasa kandungan maupun sesudah dilahirkan.

4. Anak berhak atas perlindungan terhadap lingkungan hidup yang dapat membahayakan atau menghambat pertumbuhan dan perkembangan dengan wajar.

Sedangkan berbagai upaya yang dapat dilakukan dalam upaya penanggulangan masalah gizi buruk menurut Depkes RI (2005) dirumuskan dalam beberapa kegiatan berikut :

1. Meningkatkan cakupan deteksi dini gizi buruk melalui penimbangan bulanan balita di posyandu.

2. Meningkatkan cakupan dan kualitas tata laksana kasus gizi buruk di puskesmas / RS dan rumah tangga. 
3. Menyediakan Pemberian Makanan Tambahan pemulihan (PMT-P) kepada balita kurang gizi dari keluarga miskin.

4. Meningkatkan pengetahuan dan keterampilan ibu dalam memberikan asuhan gizi kepada anak (ASI/MP-ASI).

5. Memberikan suplemen gizi (kapsul vitamin A) kepada semua balita

Mengurangi gizi buruk merupakan hal penting yang harus dilakukan, apalagi penanggulangan terhadap anak. Depkes melalu dinas kesehatan yang ada di kota/kabupaten melakukan kegiatan untuk mengurangi gizi buruk yang menimpa anak, tujuan mengurangi gizi buruk juga agar kesejahteraan anak.

Untuk menjalankan kegiatan mengurangi gizi buruk dinas melimpahkan wewenang kepada puskesmas di wilayah kecamatan dan kader-kader posyandu di wilayah pedesaan agar lebih memudahkan dalam menjalankan program-program yang telah dibuat oleh Depkes RI,

\section{METODE PENELITIAN}

Penelitian ini dilaksanakan pada Dinas Kesehatan dan Kecamatan Ngamprah Kabupaten Bandung Barat sebagai lokasi penyelenggaraan aktivitas pemerintahan dan pelayanan publik yang dilakukan oleh aparat pemerintah yang meliputi Pelayanan Kesehatan Masyarakat. Dengan pendekatan deskriptif kualitatif dan pengambilan sampel penelitian secara purposive sampling.

\section{HASIL DAN PEMBAHASAN}

Peran Dinas Kesehatan Dalam Menanggulangi Gizi Buruk Anak Di Kecamatan Ngamprah Kabupaten Bandung Barat

Gizi buruk atau malnutrisi adalah suatu bentuk terparah akibat kurang gizi menahun. Selain akibat kurang konsumsi jenis makanan bernutrisi seimbang, gizi buruk pada anak juga bisa disebabkan oleh penyakit-penyakit tertentu yang menyebabkan gangguan pencernaan atau gangguan penyerapan zat makanan yang penting untuk tubuh.

Adanya perbedaan antara gizi buruk dengan kelaparan walaupun keduanya memiliki kaitan yang erat. Kelaparan yang lama juga bisa 
berujung kepada status gizi buruk. Di Indonesia sendiri kasus malnutrisi masih tinggi.

Ini disebabkan karena faktor ekonomi keluarga tetapi sering juga didapatkan kasus gizi buruk pada anak-anak yang berasal dari keluarga menengah keatas akibat kurangnya pemahaman keluarga terhadap jenisjenis nakanan yang baik dan mengandung gizi seimbang yang harus dikonsumsi oleh anak. baca juga Status gizi anak sangat berpengaruh terhadap proses tumbuh kembang nya. Pada anak yang memiliki status gizi buruk biasanya akan terganggu nya pertumbuhan tubuh secara fisik contohnya anak akan beresiko tumbuh kecil (kerdil). Kemudian dalam perkembangan mental anak beresiko mengalami gangguan kontrol emosi dan perasaan. Disekolah anak tersebut akan sulit mengikuti pelajaran dan sulit untuk berkonsentrasi.

Pada pembahasan ini peneliti akan menggambarkan data yang diperoleh dari lapangan pada Dinas Kesehatan Kabupaten Bandung, kecamatan ngamprah UPT puskesmas ngamprah. UPT puskesmas cimareme, kader posyandu serta ibu dari anak yang menderita gizi buruk. Data dihasilkan dari hasil wawancara, pengamatan ataupun dokumendokumen yang ada kaitannya dengan penelitian, kemudian diketahui informasi mengenai fokus penelitian untuk dipelajari, dipahami dan dibaca.

Untuk menanggulangi gizi buruk ini peneliti disini peneliti memakai landasan teori menurut Rasyid untuk mendalami Peran Dinas Kesehatan Dalam Menanggulangi Gizi Buruk Anak Di Kecamatan Ngamprah Kabupaten Bandung Barat. Tiga dimensi yang dikemukakan Rasyid yaitu :

1. Pemerintah Sebagai Regulator

2. Pemerintah Sebagai Dinamisator

3. Pemerintah Sebagai Fasilitator

Dari ketiga dimensi diatas akan menjabarkan lebih sejauh mana peran Dinas Kesehatan serta mengetahui hambatan-hambatan apa saja yang dihadapi dalam menaggulangi gizi buruk dan apa saja upaya yang dilakukan oleh Dinas untuk menyikapi hambatan-hambatan yang dihadapi oleh Dinas Kesehatan, 


\section{Pemerintah sebagai Regulator}

Peran pemerintah yang mana dalam hal ini mengacu kepada Dinas Kesehatan Kabupaten Bandung Barat sebagai pelaksana fungsi regulator sebagai acuan untuk menanggulangi gizi buruk anak di Kecamatan Ngamprah Kabupaten Bandung Barat. Regulator dapat di definisikan menyiapkan arah untuk menyeimbangkan penyelenggaraan pembangunan melalui penerbitan peraturan-peraturan. Sebagai regulator, pemerintah memberikan acuan dasar kepada masyarakat sebagai instrumen untuk mengatur segala kegiatan pelaksanaan pemberdayaan.

Pembicaraan tentang regulasi yang akan mengatur hubungan antar dinas serta lembaga terkait dalam menyikapi kasus gizi buruk. . Karena kasus gizi buruk jika terjadi satu kasus saja sudah masuk klasifikasi kejadian luar biasa. Peraturan pemerintah disini dimana peraturan yang muncul dari lembaga pemerintah tujuan dibuatnya untuk melaksanakan peraturan diatasnya yaitu (undang-undang).

Berdasarkan hasil wawancara di Dinas Kesehatan Kabupaten Bandung Barat pada tanggal 14 agustus 2017 Ibu Yani sebagai staff gizi di Dinas Kesehatan Bandung Barat menyatakan bahwa regulasi dalam rangka menanggulangi kasus gizi buruk yang menimpa anak ini dituangkan dalam Peraturan Bupati Kabupaten Bandung Barat no 45 tahun 2011 tentang pelimpahan sebagian urusan kepada camat di lingkungan Kabupaten Bandung Barat menyatakan bahwa dalam bidang kesehatan upaya kesehatan yang dilakukan ialah:

1. Koordinasi penyelanggaraan operasional penanggulangan masalah kesehatan akibat bencana dan kejadian luar biasa (KLB).

2. Koordinasi penyelanggaraan penanggulangan gizi buruk.

Menurut informan dengan adanya regulasi ini Dinas Kesehatan bekerja sama dengan UPT puskesmas yang ada di daerah kecamatan guna melakukan penjaringan gizi buruk sesuai dengan laporan yang didapat dari dari kader kader posyandu. Adanya regulasi ini juga membuat Dinas Kesehatan dibatasi ruang pergerakannya hanya menunggu pelaporan kasus gizi buruk dari puskesmas. Jika di analogikan dinas disini sebagai pemamdam kebakaran yang bekerja bila ada kobaran api yang terjadi. 
Selain dari Peraturan Bupati No 45 Tahun 2011 yang menjadi acuan regulasi DINKES dalam melakukan penanggulangan gizi buruk terhadap anak ini mengacu pada buku "Pedoman Respon Cepat Penanggulangan Gizi Buruk" yang dikeluarkan DEPKES pada tahun 2008 ini yang menjadi buku saku untuk Dinas Kesehatan, Puskesmas serta Kader Posyandu untuk menanggulangi gizi buruk ini agar tidak keluar jalur dalam penanggulangan gizi buruk yang menimpa anak.

Berdasarkan observasi yang dilakukan Peneliti melihat dengan adanya regulasi yang dituangkan dalam PERBUP no 45 tahun 2011 dalam pelaksanaan penanggulangan gizi buruk berfokus ditingkat kecamatan melalui UPT puskesmas yang menjadi ujung tombak dalam menanggulangi kasus gizi buruk ini, puskesmas bersama kader posyandu ditingkat RW menjaring serta mendata setiap bulannya dilakukan pelaporan dari hasil posyandu guna ditindak lanjuti lebih lanjut lagi.

\section{Pemerintah sebagai Dinamisator}

Peran pemerintah sebagai dinamisator adalah menggerakkan partisipasi masyarakat jika terjadi kendala-kendala dalam proses pembangunan untuk mendorong dan memelihara dinamika pembangunan daerah. Pemerintah berperan melalui pemberian bimbingan dan pengarahan secara intensif dan efektif kepada masyarakat. Biasanya pemberian bimbingan diwujudkan melalui tim penyuluh maupun badan tertentu untuk memberikan pelatihan. Pemberdayaan dapat dilihat dari 2 arti. Pertama, dalam arti empowering yaitu pemberian hak atau kesempatan kepada masyarakat untuk menyampaikan dan memperjuangkan aspirasi atau menentukan masa depannya. Kedua, dalam berarti enabling yaitu proses belajar untuk meningkatkan ability,capacity dan capability masyarakat untuk melakukan sesuatu demi menolong diri sendiri. Dalam rangka pelaksanaan peran pemerintah dibidang sosialisasi dengan pemberdayaan.

Hasil wawancara di Dinas Kesehatan bersama Ibu Yani sebagai staff gizi di Dinas pada tanggal 14 agustus 2017 beliau menuturkan bahwa proses sosialisasi ini sangat penting guna menggurangi penderita gizi 
buruk, biasanya Dinas Kesehatan memerintahkan Puskesmas yang ada dikecamatan untuk melakukan lokakarya mini di desa-desa guna mengadakan penyuluhan tentang gizi buruk, hal tersebut juga dibenarkan oleh ibu Puji kasi gizi UPT puskesmas Ngamprah pada tanggal 8 agustus 2017 bahwa proses sosialisasi ataupun penyuluhan gizi buruk dilakukan lokakarya mini keliling setiap bulannya di setiap desa-desa yang ada di Kecamatan Ngamprah.

Berdasarkan hasil obervasi Peneliti disini beranggapan bahwa proses sosialisasi yang dilakukan DINKES langsung saja kepada masyarakat jangan melakukan pembekalan kepada para pegawai Puskesmas ataupun kader posyandu saja agar semua proses sosialisasi ini menjangkau ke akar permasalahan dimana kurangnya pengetahuan orang tua terhadap gizi, peneliti menilai dari beberapa informan yang diwawancarai dominan orangtua yang anaknya menderita gizi buruk itu dari kalangan pasangan muda, diawali nikah muda kurangnya kesiapan dalam hal mental para orang tua dalam mengurus anak yang menyebabkan anak memliki gizi yang kurang.

Dengan diadakannya proses sosialisasi yang hanya menjangkau Kader Posyandu dan Puskesmas saja peneliti disini melihat kurang efektif karena masyarakat atau ibu yang mempunyai anak yang kurang gizi ini tidak dapat mendapatkan informasi langsung dari ini menganai gizi buruk.

Untuk menanggulangi kasus gizi buruk pemerintah melakukan pemberdayaan kepada masyarakat terutama diberikannya pemberdayaan bahwa akan sadar seberapa penting pemberdayaan dalam rangka penanggulangan gizi buruk yang menimpa anak.

Dari hasil wawancara dengan ibu Yani staff gizi di Dinas Kesehatan pada tanggal 14 agustus menuturkan bahwa pemberdayaan yang dilakukan dinas biasanya didampingi kader posyandu di psoyandu seperti memberikan makanan apa saja yang sehat di konsumsi anak, DINKES pun memberikan pemulihan makanan tambahan (PMT), dan Susu. Dalam distribusinya PMT ini diberikan kepada masyarakat jika sudah masuk klasifikasi gizi buruk baru bisa mendapatkan PMT agar tetap sasaran. 
Dari hasil wawancara lainnya menurut Ibu Dewi Kasi Gizi di Puskesmas Cimareme menuturkan bahwa pemberdayaan yang dilakukan oleh puskemas biasanya bekerja sama dengan Posyandu melakukan penimbangan secara berkala 2bulan, 3bulan jika dalam kurun waktu tersebut masih menderita gizi buruk anak tersebut disebut GBM garis bawah merah.

Dalam mengoptimalkan proses pemberdayaan ini menurut Ibu Yani staff gizi Dinas Kesehatan menuturkan untuk mengoptimalkan proses pemberdayaan ini dilakukan nya pemberian pembekalan kepada kader posyandu maupun pegawai puskesmas dalam rangka pemberdayaan kepada ibu-ibu orangtua anak yang menderita gizi buruk. Hal senada dikatakan Ibu Eko kader Posyandu mengatakan bahwa ia dibekali kemampuan pengetahuan tentang gizi buruk untuk nanti disampaikan lagi di Posyandu.

Hal tersebut juga dibenarkan oleh Ibu Rini orangtua dari anak yang menderita gizi buruk beliau mengatakan bahwa dia mendapatkan pemberdayaan hanya di tingkat Posyandu yang dberikan oleh Ibu Eko berupa pemahaman untuk memasak makanan bergizi dengan diberikan arahan dalam pola asuh kepada anak yang benar.

Dari hasil observasi Peneliti disini berpandangan proses dari pengoptimalan proses pemberdayaan tersebut dilakukan dahulu di tingkat kecamatan dengan mengadakan acara lokakarya mini disetiap kecamatan yang dilakukan oleh DINKES dengan sasaran pegawai staff gizi ditingkat Puskesmas beserta kader Posyandu yang menjadi ujung tombak dalam penanggulangan gizi buruk ditingkat paling bawah RW, agar tepat sasaran dalam proses pemberdayaan ini supaya optimal ibu-ibu yang mempunyai anak gizi buruk diberikan buku saku untuk mengukur, menulis hasil penimbangan pengukuran tinggi badan secara berkala.

Dalam proses pemberdayaan ini dinas menemui kendala banyaknya orangtua anak yang enggan datang ke posyandu untuk mengikuti pemberian pembekalan makanan yang diberikan kepada anak, dimana rasa malas dan malu yang menyebabkan orangutan enggan datang ke posyandu yang ada di Desa-desa. Untuk mengakali hal tersebut kader posyandu terus 
mengajak para orangtua untuk datang ke posyandu sehingga aktif untuk mengikuti posyandu secara berkala sehingga bisa memberikan anaknya makanan yang bergizi.

\section{Pemerintah Sebagai Fasilitator}

Peran pemerintah sebagai fasilitator adalah menciptakan kondisi yang kondusif bagi pelaksanaan pembangunan untuk menjembatani berbagai kepentingan masyarakat dalam penelitian ini fasilitas apa saja yang diberikan dari Dinas Kesehatan Kabupaten Bandung Barat untuk menanggulangi gizi buruk anak di Kecamatan Ngamprah pemberian modal ataupun bentuk fasilitas guna memberdayakan masyarakat.

Dari hasil wawancara dengan Ibu Yani staff gizi di Dinas Kesehatan Bandung Barat pada tanggal 14 agustus 2017 beliau memaparkan bahwa dinas sudah memberikan fasilitas kepada puskesmas ataupun posyandu berupa pemberian dacin (mesin penimbang berat badan anak), pengukuran tinggi badan, serta poster-psoter yang diberikan kepada puskesmas terus di distribusikan ke posyandu-posyandu ditiap RW di desa-desa yang ada di Kecamatan Ngamprah, selain itu fasilitas yang berikan Dinas Kesehatan memberikan kegiatan posyandu secara teratur bergilir disetiap RW secara teratur.

Menurut informan lain ibu Dewi kasi gizi Puskesmas Cimareme terkait fasilitas apa yang diberikan untuk menanggulangi gizi buruk anak, beliau berpendapat bahwa fasilitas diberikan puskesmas menindak lanjuti kasus gizi buruk anak yang parah untuk segara ditindak lanjuti dirujuk ke rumah sakit yang berhubungan untuk segera ditanggani, puskesmas cepat tanggap jika ada satu saja penderita gizi buruk karena ada satu aja anak yang terkenan gizi buruk digolongkan kejadian yang luar biasa (KLB) jadi dalam penangganannya pun tidak main-main, DINKES dan Puskesmas sangat menanggapi fenomena gizi buruk yang menimpa anak, biasanya pegawai puskesmas langsung datang kerumah yang menderita guna melihat langsung berdasarkan pelaporan kader posyandu guna ditindak lanuti lebih lanjut lagi. 
Begitupun dengan informan Ibu Puji Kasi Gizi di Puskesmas Mengatakan bahwa fasilitas yang diberikan oleh DINKES ini biasanya diberikan 3 bulan dalam melakukan penanggulangan gizi buruk ini, dan juga pemberian Dacin (timbangan anak) alat pengukur tinggi badan, serta buku-buku yang disebar oleh Kader Posyandu kepada ibu yang anaknya menderita gizi buruk

dari hasil wawancara dengan Ibu Yani Staff Gizi di Dinas Kesehatan pada tanggal 14 agustus 2017 terkait dengan hambatan apa yang dihadapi dinas dalam melakukan penanggulangan gizi buruk dibliau mengutarakan bahwa Dinas dihdapkan dengan para korban gizi buruk yang disertai penyakit penyerta bawaan dari lahir, dimana jika ada penderita gizi buruk yang menimpa anak jika disertai penyakit penyerta dalam penanggulangannya akan lama, khusus bagi penderita gizi buruk yang disertai penyakit penyerta ini diberikan perhatian khusus dari dinas.

Dari wawancara lainnya Ibu Puji Kasi gizi puskesmas ngamprah juga berkata demikian bahwa jika gizi buruk yang disertai penyakit penyerta contohnya Zahra yang tinggal di desa margajaya ini menderita gizi buruk sejak lahir dalam menaikan berat badan sangat sulit.

Peneliti memandang bahwa dalam pemberian fasilitas hasil wawancara dengan instansi dinas maupun Puskesmas disini peniliti menilai bawasannya dinas beserta puskesmas sangat serius dalam memberikan fasilitas guna menanggulangi gizi buruk ini.

Dalam menanggapi hambatan-hambatan yang dihadapi oleh DINKES dengan instansi terkait, untuk mengatasi masalah dari penanganan gizi buruk ini dikemukakan oleh Ibu Rini orangtua dari anak yang menderita gizi buruk dimenuturkan bahwa diberikan bantuan pengobatan gratis di rumah sakit yang ada di Bandung raya yang diberikan langsung oleh dinas yang bekerja sama dengan rumah sakit, jadi gaperlu bayar biaya rumah sakit lagi, tinggal nyiapin dokumen saja.

Hal tersebut juga diungkapkan ibu Rini orang tua anak yang menderita gizi buruk membenarkan DINKES memberikan fasilitas berupa bantuan untuk berobat langsung ke RSUD Hasan Sadikin, selain biaya berobat yang gratis orang dari DINKES juga memberikan ongkos untuk 
berangkat berobat, ibu tini katanya pegawai dinas yang sering memberikan ongkos untuk berangkat ke rumah sakit. Tapi Ibu Tini sudah pindah tugas jadi tidak lagi ada yang memberikan bantuan berupa uang untuk ongkos berobat.

Begitupun wawancara dengan Ibu Puji kasi Gizi di UPT Puskesmas Ngamprah beliau menuturkan bahwa dalam penanggulangan gizi buruk ini Puskesmas melakukan upaya seperti sosialisasi di Desa-desa yang dihadari Kader-kader posyandu untuk diteruskan kembali informasi tentang gizi buruk ini kepada masyarakat. Beliau beranggapan upaya terus diupayakan dari dinas kepada masyarakat dalam melakukan penanggulangan gizi buruk ini.

Berdasarkan hasil observasi Peneliti melihat bahwa upaya yang dilakkan oleh Dinkes atau instansi terkait dalam menanggulangi gizi buruk sudah cukup optimal dimana banyaknya sambutan positif dari masyarakat yang membenarkan bahwa dinas memberikan pemberdayaan terkait masalah gizi buruk.

Upaya dilakukan oleh Puskesmas juga memberikan penyuluhan di desa desa dengan mengadakan lokmin guna memneritahukan tentang masalah gizi buruk yang terjadi di Kecamatan Ngamprah, pemerintah setempat pun ikut andil dalam melakukan penyuluhan disini sebatas menfaslitasi tempat untuk melakukan penyuluhan agar terlaksana dengan lancar.

\section{KESIMPULAN}

Berdasarkan hasil penelitian dan pembahasan mengenai Peran Dinas Kesehatan Dalam Menanggulangi Gizi Buruk Anak Di Kecamatan Ngamprah Kabupaten Bandung Barat, peneliti dalam penelitian ini menyimpulkan bahwa dalam melaksanakan tugas dan fungsinya dinas kesehatan Dinas Kesehatan sudah melaksanakan peran cukup optimal dilihat dari enam indikator keberhasilan penanggulangan gizi buruk yaitu :

1. Seluruh Posyandu melaksanakan operasi timbang minimal sekali sebulan Seluruh balita ditimbang

2. Seluruh balita gizi buruk ditemukan 
3. Seluruh kasus gizi buruk dirujuk ke Puskemas Perawatan atau Rumah Sakit

4. Seluruh kasus gizi buruk dirawat di Puskesmas Perawatan atau runah sakitditangani sesuai tatalaksana baita gizi buruk.

5. Seluruh balita gizi buruk pasca perawatan mendapatkan pendampingan

Dalam melaksanakan tugas dan fungsinya untuk menanggulangi gizi buruk anak dinas kesehatan berperan sebagai berikut : Pertama, Dinas dalam rangka melaksanakan menggurangi gizi buruk anak berdasarkan aturan-aturan yang berlaku dilingkungan yang dikeluarkan oleh Bupati, maksud dan tujuan dibuat aturan tersebut dimaksudkan agar dinas beserta puskesmas mempunyai pedoman dalam melaksanakan penanggulangan gizi buruk ini agar tepat sasaran. Kedua, dalam hal sosialisasi dan pemberdayaan dinas memberikan bekal penyuluhan kepada kader maupun pegawai Puskesmas guna mensosialisasi disetiap desa-desa dilakukan lokakarya mini tentang gizi buruk ini, dalam hal pemberdayaan Dinas beserta Puskesmas memberikan pelatihan kepada orangtua tentang pengetahuan makanan bergizi, selain itu Dinas memberikan Pemulihan Makanan Tambahan (PMT) dengan susu yang diberikan selama 3bulan pengawasan kader posyandu secara instensif. Ketiga, dalam hal fasilitas Dinas memberikan fasilitas untuk penanggulangan gizi buruk ini memberikan dacin (timbangan anak), pengukur tinggi badan anak, serat memberikan buku saku untuk memonitor perkembangan berat badan pada anak.

Hambatan-hambatan yang dihadapi Dinas dalam penanggulangan gizi buruk buruk ini adalah : Pertama, hambatan yang dihadapi oleh dinas dalam penanggulangan gizi buruk ini jika penderita gizi buruk ini dari kalangan non-gakin (keluarga miskin) dimana orangtua dari anak enggan membawa anak ke posyandu terdekat sehingga tidak terkontrol langsung oleh petugas posyandu. Kedua, hambatan yang dinas ini ialah dimana anak yang menderita gizi buruk ini disertai dengan penyakit penyerta yang membuat berat badan enggan anik setiap bulannya,

Upaya yang dilakukan Dinas dalam mengatasi hambatan yang dihadapi untuk melakukan penanggulangan gizi buruk, khusus untuk gizi 
buruk yang disertai penyakit penyerta dinas melakukan kerja sama dengan rumah sakit yang ada di daerah bandung raya. Jika ada penderita gizi buruk dari keluarga kurang mampu bisa berobat dengan gratis.

Pada umumnya gizi buruk yang menimpa anak ini terjadi karena masalah ekonomi, sulitnya orangtua korban mencari pekerjaan yang mengakibatkan anak terkena gizi buruk, selain itu gizi buruk juga disebabkan oleh penyakit penyerta yang dibawa sejak lahir.

\section{SARAN}

1. Dalam hal sosialisasi ini dinas maupun instansi terkait seharusnya langsung memberikan penyuluhan langsung kepada warga agar dalam penyampaian gizi buruk ini dapat dipahami langsung oleh warga

2. Perlu adanya sikap kritis masyarakat kepada pemerintah dalam melakukan penyuluhan langsung kepada setiap masyarakat guna dalam proses sosialisasi tersebut dapat tersampaikan

3. Adanya program pendidikan tentang gizi buruk yang disampaikan langsung oleh dinas keseshatan

4. Adanya penyuluhan langsung yang dilakukan dinas guna langsung diserap oleh masyarakat

5. PMT harus dibagikan secara merata kepada masyarakat agar tidak salah sasaran.

\section{DAFTAR PUSTAKA}

Arikunto. 2006. Prosedur penelitian : suatu pendekatan praktik. Jakarta: Rineka Cipts

Biddle, B. B., \& Thomas, E. J. (Eds.). 1966. Role theory: Concepts and research . New York: Wiley.

Creswell, J.W. 1994 Research Design Qualitative And Quantitative Approaches. Sage Publications. London.

Rasyid.M, 2000. Otonomi Daerah Negara Kesatuan, Yogyakarta : Pustaka Pelajar.

Soekanto, Soerjono, 2002, Teori Peranan, Jakarta, BumiAksara.

Soekanto, Soerjono. 2004. Sosiologi Suatu Pengantar.Jakarta:Raja Grafindo Persada

Sugiyono. 2014. Metode pendidikan Penelitian Kuantitati fKualitatif. Bandung :Alfabeta

Suhardjo, 2003. Berbagai Cara Pendidikan Gizi. Jakarta : Bumi Aksara 
Syafiie. Inu kencana. 2005. Pengantar Ilmu Pemerintahan. Bandung : Refika Aditama

Ndraha, Taliziduhu, 2000. IlmuPemerintahan (Kybernology), Jakarta: RinekaCipta.

Neuman. W. L. 2003, Social Research Methods Qualitative And Quantitative Approaches. Boston. Allyn and Bacon 